Dermatology 2009;218:387-388

DOI: $10.1159 / 000167830$

\section{Unilateral Agminated Melanocytic Nevi}

Miguel Cabanillas Gonzáles, Benigno Monteagudo, Cristina de las Heras, Jose María Cacharrón

Department of Dermatology, Complejo Hospitalario Arquitecto Marcide-Novoa Santos, Ferrol, Spain

\section{Key Words}

Melanocytic nevi, agminated $\cdot$ Blaschko lines

We read with great interest the article entitled 'Acquired unilateral melanocytic nevi in otherwise normal skin' by Yu et al. [1]. We recently admitted in our clinic another case of unilateral melanocytic nevi, clustered together (agminated), but also following the lines of Blaschko. There have been several reports of agminated nevi, many of them corresponding to Spitz or blue nevi [2-3] and few describing true melanocytic nevi [4-6]. A blaschkoid pattern of agminated melanocytic nevi has rarely been reported in the literature [7-9].

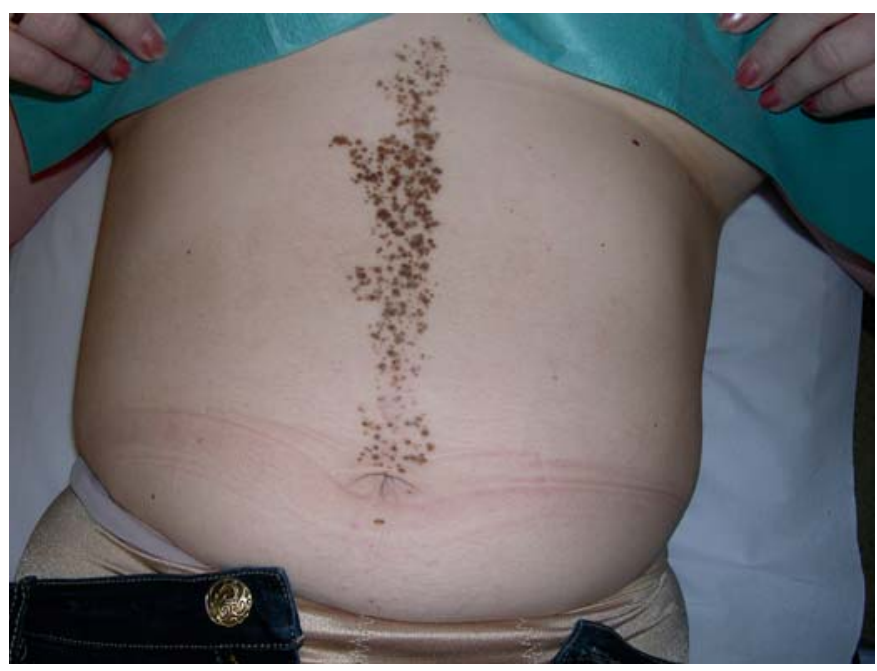

Fig. 1. Multiple agminated melanocytic nevi distributed on the midline of the anterior wall of the abdomen, showing extensions along Blaschko's lines to the right side of the abdomen.
A 55-year-old woman presented for the examination of numerous moles on her anterior abdominal wall. The pigmented lesions had been present at birth and had not recently changed in size, color or texture. Clinical examination showed multiple dark brown macules that ranged from 2 to $8 \mathrm{~mm}$ in size, arranged from the midline of the anterior abdominal wall to the right side of the abdomen following a Blaschko linear pattern (fig. 1). No signs of dysplastic nevi were present. Skin biopsy of one pigmented lesion showed numerous pigmented nevus cell nests along the dermoepidermal junction with melanophages in the dermis (fig. 2).

'Agminated' is derived from the Latin word 'agmen', meaning 'aggregation'. Agminated melanocytic nevi tend to be clustered together in a circumscribed region, sometimes in a segmental area. Few reports of unilateral multiple melanocytic nevi are present in the literature $[1,4,7-9]$, sometimes, as in our case, arranged in a linear distribution resembling the lines of Blaschko [7-9]. Other reports describe a segmental distribution corresponding to the trigeminal dermatome [4]. This linear distribution may be due to a clonal outgrowth of cells which carry a major gene responsible for the development of melanocytic nevi. This clone is thought to originate from a somatic mutation at an early stage of embryogenesis. The risk of malignant change in agminated melanocytic nevi is unknown. However, melanoma arising from agminated melanocytic nevus has been described [10], and longterm follow-up is recommended.

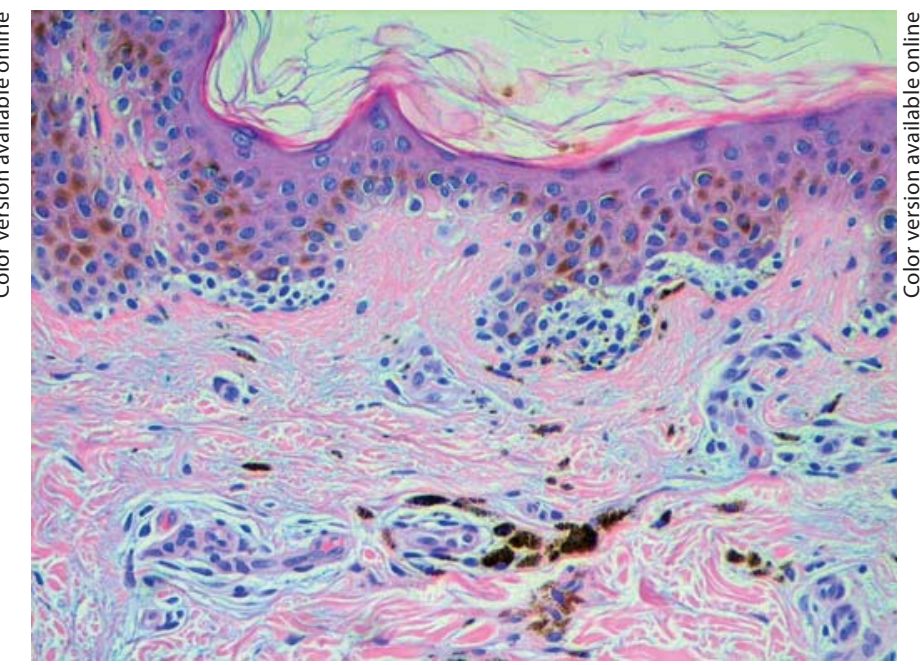

Fig. 2. Nevus cell nests along the dermoepidermal junction with melanophages in the dermis.

\section{KARGER}

두 2008 S. Karger AG, Basel

Fax +41613061234 E-Mail karger@karger.ch www.karger.com 


\section{References}

1 Yu X, Nagai H, Nishigori C, Horikawa T: Acquired unilateral melanocytic nevi in otherwise normal skin. Dermatology 2008;217:63-65.

$\checkmark 2$ Glasgow MA, Lain EL, Kincannon J: Agminated Spitz nevi: report of a child with a unique dermatomal distribution. Pediatr Dermatol 2005; 22:546-549.

3 Pizzichetta MA, Soyer HP, Massone C, Cerroni L: Clinical and dermoscopic features of agminated blue nevus. Arch Dermatol 2007;143: 1225-1226.

4 Brunner M, Vardarman E, Megahed M, Ruzicka T: Congenital agminated segmental naevi. Br J Dermatol 1995;133:315-316.

5 Martin JM, Pizano MI, Monteagudo C, García L, Jordá E: Congenital agminated nevi on the trunk. Int J Dermatol 2003;42:942-943.

-6 Monteagudo B, León A, García Prieto W, Rodríguez-Blanco I, GarcíaRego A, de las Heras C, Cacharrón JM: Nevus melanocíticos adquiridos agminados. Actas Dermosifiliogr 2005;96:405-406.

-7 Effendy I, Happle R: Linear arrangement of multiple congenital melanocytic nevi. J Am Acad Dermatol 1992;27:853-854.
8 Nachbar F, Merkle T, Ruzicka T: Congenital junctional nevi following Blaschko's lines. Eur J Dermatol 1993;3:478-479.

-9 Bañuls J, Ramon R, Guijarro J, Alfonso R, Silvestre JF, Climent JM, Botella R: Segmental arrangement of multiple, partly congenital and partly acquired melanocytic nevi. Eur J Dermatol 1998;8:80-82.

10 Corradin MT, Alaibac M, Fortina AB: A case of malignant melanoma arising from an acquired agminated melanocytic naevus. Acta Derm Venereol 2007;87:432-433.

Dr. Miguel Cabanillas González

Departamento de Dermatología, Hospital Básico de la Defensa Complejo Hospitalario Arquitecto Marcide-Novoa Santos Ctra San Pedro-Catabois, s/n

ES-15405 Ferrol (Spain)

Tel. +34981563 100, Fax +34981547094

E-Mail miguel.cabanillas.gonzalez@sergas.es 